\title{
Environmental accounting for sustainable development: An empirical study in Vietnam
}

\section{Nguyen Phu Giang ${ }^{a}$, Ta Quang Binh ${ }^{a^{*}}$, Lai Thi Thu Thuya, Dao Ngoc Ha ${ }^{a}$ and Cao Hong Loan}

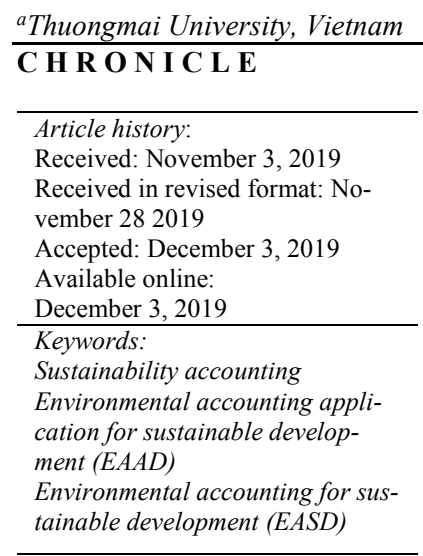
\begin{abstract}
A B S T R A C T
This article provides an overview of environmental accounting for sustainable development such as approach, measurement of sustainable accounting and assess the impact of factors on the application of environmental accounting for sustainable development. The information of 80 companies used for research have been representatively selected from manufacturing, mining and processing industries, state ownership and non-state ownership, in export processing zones and outside export processing zones at all scales of number of employees, equity, revenue in Vietnam. Data is analyzed using multivariate linear regression. Research shows that factors such as managers' perceptions of costs and benefits, environmental changes, characteristics of the scale of production and business activities of enterprises, pressures to announce sustainable environmental information and reporting have significant influences on the development of environmental accounting for sustainable development.
\end{abstract}

\section{Introduction}

Companies around the world are increasingly being challenged to expand their financial reporting to include profiteering goals as well as social efforts made to improve the environment. The measurement and publication of information on the impact of business activities in enterprises on sustainable development is the task of environmental accounting for sustainable development. At this level, sustainable accounting as a business philosophy is quickly gaining momentum in this millennium, especially when facing international adoption. Sustainability is often considered the integration of three performance areas: economic, social and environmental. It is also considered a necessary practice for the existence of modern business companies. Poveda and Young (2015) proposed that organizations over time have realized that meeting stakeholders' expectations is a necessary condition for sustainability and therefore necessary to achieve goals. Overall business strategy, challenges are given to modern-day managers on how to manage performance on sustainable aspects to get integrated benefits from implementation strategies (Poveda \& Young, 2015).

Nnamani et al. (2017) argue that the key for managing organizational progress in a sustainable way is in measuring what cannot be measured and we may find it difficult to manage. It can be said that environmental accounting for sustainable development is influenced by a variety of factors. This may include the size of the business, the characteristics and nature of the business and production activities of the enterprise, the awareness of the enterprise administrator, the barriers of the institutions and regulations, etc. It is essential to determine the degree of influence of each factor on environmental accounting for sustainable development.

\footnotetext{
* Corresponding author.

E-mail address: binhtq@tmu.edu.vn (T. Quang Binh)

(C) 2020 by the authors; licensee Growing Science, Canada doi: $10.5267 /$ j.msl.2019.12.005
} 


\section{Literature Review}

\section{Accounting stance on sustainable development}

Despite a large number of sustainable development initiatives, the lack of uniform standards, regulations and plans still presents challenges to contemporary sustainable accounting. Accounting requires a more realistic response to sustainable development. This will facilitate the formation of government policies and institutions on sustainability. Issues such as carbon accounting and sustainable accounting are regulated and developed to address the challenges of climate change (Ngwakwe, 2012). Each company must undergo a sustainable and transparent report of the company and the company must focus on environmental reporting. Disclosure of non-financial information is in particular bribery, corruption, human rights and human capital management. The company's future sustainability must be at the centre of corporate decision-making and this must enrich not only individual businesses but also the quality of the stock market, because of superior information, instead of short-term incomplete data will begin to identify the market (Raju \& Rao, 2016).

\section{Content of environmental sustainability accounting}

The increasing exploitation of natural resources and waste and emissions due to the use of them directly or indirectly is responsible for humanity to approach or even cross important planetary boundaries. A solid knowledge based on social metabolism, that is, the processes of physical exchange between society and the natural environment and related production and consumption processes is necessary to develop more sustainable resource use strategies. The economy-wide flow of raw materials is a framework that provides consistent aggregates of input materials for national economies, changes in material reserves in the economic system and the beginning to materialize to other economies and environments. The term "natural resources" is now widely used to describe components of the natural environment (minerals, fuels, animals and plants, ecosystems). Therefore, the urgent need to implement more efficient methods of accounting for "natural resources" to manage them is currently not reflected in standard accounts. These issues should be incorporated into relevant economic and environmental policies (Terama et al., 2015). Each stage of coal mining, transportation, treatment and burning creates a stream of waste and carries health and environmental hazards. The authors estimate that the lifetime impact of coal and waste generated costs the US \$ 300-500 billion annually. This damage is three times the price of electricity per kWh generated from clean sources such as solar and other forms of non-fossil energy production (Epstein et al., 2011). This article focuses on a specific class of water integration issues, related to salt water management. One case study is used to illustrate the proposed method and to highlight the importance of accounting consider zero liquid discharge, to develop basic design for alternating water networks. For a with the industrial city layout, four different scenarios have been implemented, and each case is linked with some waste water.

\section{Theoretical Framework of Research}

\section{Sustainable accounting - approach and measure}

The role of business and accounting for sustainable development is reflected in the European Environmental Commission's Fifth Action Program, entitled Towards Sustainability (European Commission, 1992), therefore business and accounting are related to sustainable development because of industrial pressure on environmental results from two main factors: production and consumption levels, and environmental pressure on each production unit and consume. The implication is the need to reduce the environmental pressure on each production and consumption unit. In order for this reduction to be effective, effective measurement is required through the recognition and assignment of prices and costs for natural resources. Accounting must be a tool for desirable measurements to enhance corporate environmental management, because accounting information guides planning and decision management activities and thus affects corporate behaviour (Ngwakwe, 2012). Sustainability accounting is a tool used by organisations to become more sustainable. The most known widely used measurements are the Corporate Sustainability Reporting (CSR) and triple bottom line accounting. These recognise the role of financial information and show how traditional accounting is extended by improving transparency and accountability by reporting on the Triple-P's (Jeffery et al., 2012). Sustainable accounting unifies the company's strategies by providing environmental, economic and social information. In reality, however, it is difficult to put in place policies that promote all three goals at the same time. Environmental accounting for sustainable development (EASD) can be defined according to three perspectives:

1) The environment represents the collection of natural resources;

2) The environment shows the interaction between natural resources and human activities;

3) Environment is a collection of all available resources

According to three views, environmental accounting for sustainable development can be structured as follows:

1) Accounting will only consider the costs and investments related to the protection of natural resources;

2) Accounting takes into account, besides the costs and investments related to environmental protection, some series of additional activities can compete directly or indirectly with the creation of impacts such as costs and investments related to transport, global warming, urbanization, agriculture and improvement animal; 
3) The accounting system is changing completely; therefore, an environmental / social balance is imposed, to show all cost lines to support the sustainable development of aria. The authors believe that EAAS should be analysed based on the classification of accounting users into two categories:

1) Environmental Accounting (EA) is an accounting for external users that must be notified in single currency units also in physical units;

2) Environmental management accounting (EMA) is held in the interests of internal users in monetary units and in physical units.

According to $\mathrm{OECD}$, there are two different approaches to accounting framework for sustainable accounting: (1) Measuring environmental-social-social interrelationships, (2) Wealth-based approaches

Measuring environmental-economic-social interrelationships requires a specific understanding of the relationships between natural and economic environments. Physical flow accounts are very useful in expressing characteristics of production and consumer activities. These accounts focus on physical exchange between the economic system and the natural environment.

Wealth-based approaches to sustainability: This approach refers to preserving wealth. Sustainability is considered the maintenance of a nation's capital and is capable of being measured. In the Financial Statements, businesses need to reflect some environmental changes over a period of accounting.

The Global Reporting Initiative (GRI) provides advanced documents that help organizations create accountability reports. This document helps organizations become more sustainable in their day-to-day business activities.

Specific techniques to measure information in sustainability accounting include: (1) Inventory Approach, (2) Sustainable Cost Approach, (3) Resource Flow / Input-Output Approach

The Inventory Approach focuses on different types of natural resources, their consumption in the business of the business. This approach identifies, records, tracks, and reports on different types. These types are analysed according to the specific classification, including critical, non-renewable/non-substitutable, non-renewable/substitutable, and renewable natural capital

The Sustainable Cost Approach leads to quantification of a number of income statements showing the failure of the organization to leave the biosphere at the end of the accounting period not worse than the beginning of the accounting period. In other words, how much this represents the cost of an organization is to return the biosphere to a natural state at the beginning of the accounting period.

The Resource Flow / Input-Output Approach tries to report the organization's resource flows. This approach focuses on the resources used by the business. This approach lists the resources flowing into and out of the organization to accurately identify the resources that the unit used or compensated for the environment.

\section{Contents of environmental accounting for sustainable development}

Environmental accounting for sustainable development (EASD) includes the following issues: Improving access to services and resources, managing supply and demand, improving the state of environment and reducing impacts, mitigating risks and adapting to extreme events.

Improving access to services and resources focuses on policies to ensure individuals' access to appropriate, reliable and affordable resources and services reasonable. The disadvantage that individuals may have is not only related to the volume of resources in a given country, but also the ability to access that resource. sustainable environmental accounting can create measures to guide policy makers in assessing and managing suppliers of resources such as water and energy. They include the following indicators:

- Current and capital costs associated with provision of services and their financing;

- Distribution losses;

- The amount of resources used.

Managing supply and demand focuses on the allocation of natural resources to meet the needs of current and future generations based on available resources. They include the following key indicators:

- The use of resources for production and consumption;

- The creation of emissions and waste of activities in the enterprise;

- The efficiency of resources used;

- Determining values for emissions and use of resources, the carbon and energy contained in the products, environmental goods and services, green jobs;

- Determining the size specified for the database because to remove it (such as creating a database or environment with additional value);

- The rent related to the resource; Investments in infrastructure. 
Improvement of the state of the environment and reduction of impacts notes the possibilities of nuisance of economic activities but also their ability to protect or restore natural capital for future benefits. The EASD provides a recognized approach for the international comparison of measures such as:

- The stock of natural resources;

- Emissions to water, air and soil, as well as the production of waste;

- Expenses related to environmental preservation and resource management;

- Use and cover the soil;

- The inventory and status of ecosystems;

- Regulatory service provided by ecosystems;

- Economic tools to reduce impacts;

The EASD is also developing "good practices" on measures such as:

- The inventory and state of ecosystems;

- Regulatory service provided by ecosystems.

Finally, risk management and adaptation to extreme events, refers to policies aimed at reducing the human, economic and ecological nuisances that are created by extreme natural events and a climate change.

\section{Factors affecting the application of environment accounting for sustainable in Vietnam}

\section{Measuring Scale of Variables}

The study uses the scale to measure the extent of Hanini and Abdullatif (2013) accountancy application and continues to develop the balanced scorecard method (two items). Based on previous research, the paper has evolved into 15 new variables to survey for manufacturing enterprises in Vietnam.

\section{The Population of the Study}

The population of the study is represented by Vietnam's firms of production, the sample which was represented by a random sample and consists of the general managers and accountants. 272 questionnaires are distributed and 250 are retrieved representing $91.9 \%$ of the sample size. To support for the survey research, the Likert scale is used. The format of five-point Likert scale is: 1 = "very low"; 2 = "low"; 3 = "medium"; 4 = "high"; 5 = "very high". Structure of the research sample: About respondents (26.4\% of managers and $73.6 \%$ of accountants), about the field of business activities ( $46 \%$ of enterprises mining \& processing, $54 \%$ of production), about type of ownership (42,4\% is state ownership, $57,6 \%$ owned not state), about the number of workers (34\% of enterprises under 100 people, $30.8 \%$ from 100 to 200, 35.2\% more than 200 people), regarding equity $(24.4 \%$ of enterprises have equity of less than 1 million dollars, $31.6 \%$ from 1 million to 5 million dollars, $44 \%$ greater than 5 million dollars).

After collecting data, according to the part and the group of these data in the questionnaire, they are changed and encoded in Microsoft Excel. Then, SPSS 22.0 is applied to analyse these data. This study is designed to test the level of application of environmental accounting for sustainable development in manufacturing enterprises in Vietnam today. Research will answer key questions:

- What is the current level of application of environmental accounting for sustainable development in manufacturing enterprises in Vietnam?

- What should be done to improve the application of environmental accounting for sustainable development in manufacturing enterprises in Vietnam today?

The Hypotheses of the study and the items of the hypotheses

Based on the theoretical frame and the previous studies, the following hypotheses were formed:

The first hypothesis:

H1: EASD is not under the pressure of owners. This hypothesis is tested through the items:

Table 1

The Items of the first hypothesis:

Pressure on stakeholders

$\begin{array}{ll}1 & \text { Awareness and interest of the community on environmental issues and sustainable development issues } \\ \text { (PRESS.AWAR) }\end{array}$


The second hypothesis:

H2: The awareness of senior managers does not affect EASD. This hypothesis is tested through the items:

Table 2

The Items of the second hypothesis:

\begin{tabular}{ll}
\hline \multicolumn{2}{c}{ Awareness of senior managers } \\
\hline 4 & $\begin{array}{l}\text { Awareness of senior managers on implementing environmental strategies in a active and positive manner } \\
\text { (AWAR.STRA) }\end{array}$ \\
5 & $\begin{array}{l}\text { Awareness of senior managers about the uncertainty and change of the environment (AWAR.CHANGE) } \\
\text { The view of the senior administrator about the benefits and costs of implementing environmental accounting } \\
\text { (AWAR.BENEFI) }\end{array}$ \\
\hline
\end{tabular}

The third hypothesis:

H3: Business characteristics of enterprises do not affect EASD. This hypothesis is tested through the items:

Table 3

The Items of the third hypothesis:

\begin{tabular}{ll}
\hline & Business characteristics of enterprises \\
\hline 7 & The size of the business (CHARAC.SCALE) \\
8 & $\begin{array}{l}\text { Characteristics of products produced, exploited and processed (CHARAC.PRODUC) } \\
\text { Characteristics of regions and regions where enterprises set up production, processing and exploitation establish- } \\
\text { ments (CHARAC.LOCAL) }\end{array}$ \\
\hline
\end{tabular}

The fourth hypothesis:

H4: Pressure to comply with environmental protection laws does not affect EASD. This hypothesis is tested through the items:

Table 4

The Items of the fourth hypothesis:

\begin{tabular}{ll}
\hline & Pressure to comply with environmental protection laws \\
\hline 10 & Pressure on mining licenses and production, business certificates (LAW.LICENCE) \\
11 & $\begin{array}{l}\text { Pressure on ensuring necessary environmental indicators are regulated for products and services of enterprises } \\
\text { (LAW.INDICATOR) }\end{array}$ \\
12 & $\begin{array}{l}\text { Pressure to publish environmental information, environmental reports and sustainable development (LAW.DIS- } \\
\text { CLO) }\end{array}$ \\
\hline
\end{tabular}

\section{The fifth hypothesis:}

H5: Financial, information and institutional barriers affect EASD. This hypothesis is tested through the items:

\section{Table 5}

The Items of the fifth hypothesis:

\begin{tabular}{ll}
\hline \multicolumn{3}{c}{ Financial, information and institutional barriers } \\
\hline 13 & Financial barriers (BARR.FINAN) \\
14 & $\begin{array}{l}\text { Information barriers (Difficulties in collecting environmental information: Environmental costs, environmental lia- } \\
\text { bilities; environmental variability: climate change or natural disasters or changing environmental awareness Eco- } \\
\text { logical ...) (BARR.INFOR) }\end{array}$ \\
\hline 15 & Institutional barriers (power of shareholders, stakeholders ...) (BARR.INSTITU) \\
\hline
\end{tabular}

The sixth hypothesis

H6: Business benefits do not affect EASD. This hypothesis is tested through the items:

Table 6

The Items of the sixth hypothesis:

\begin{tabular}{ll}
\hline & Benefits of the business \\
\hline 16 & $\begin{array}{l}\text { Profit pressure (Reduce costs of raw materials and resources, increase costs for environmental protection ...) } \\
\text { (BENE.PROFIT) }\end{array}$ \\
17 & Pressure on brand and reputation of enterprises (BENE.BRAN) \\
18 & Desire to use effectively, reasonably, economically, for the right purposes of resources (BENE.EFFICIEN) \\
\hline
\end{tabular}




\section{Research results}

Cronbach's alpha was used to measure the reliability of scale and it was equal to 0.913 . The research result shows that Cronbach's alpha is high level of internal consistency for all scales with this specific sample.

Table 7

The summary of the final value measured for Cronbach Alpha

\begin{tabular}{lrrrr}
\hline & $\begin{array}{c}\text { Scale Mean if Item } \\
\text { Deleted }\end{array}$ & $\begin{array}{c}\text { Scale Variance if } \\
\text { Item Deleted }\end{array}$ & $\begin{array}{c}\text { Corrected Item-To- } \\
\text { tal Correlation }\end{array}$ & $\begin{array}{c}\text { Cronbach's Alpha if Item De- } \\
\text { leted }\end{array}$ \\
\hline PRESS.AWA & 19.8920 & 11.719 & .857 & .910 \\
PRESS.INFORM & 19.8880 & 11.650 & .869 & .879 \\
PRESS.COMMITM & 19.8560 & 11.586 & .845 & .881 \\
\hline
\end{tabular}

1) Awareness of senior managers (Cronbach Alpha $=0.931)$, Business characteristics of enterprises $($ Cronbach Alpha $=$ 0.943), Pressure to comply with environmental protection law (Cronbach Alpha $=0.949$ with variable LAW.INDICATOR is excluded), Financial, information and institutional barriers (Cronbach Alpha $=0.692$ with variable BARR.INSTITU is excluded), Benefits of the business (Cronbach Alpha 0.742 with variable BENE.PROFIT is excluded)

Exploratory Factor Analysis (EFA)

$\mathrm{Sig}=0.000<0.05, \mathrm{KMO}=0.938>0.5$ Conditions for analysing the KMO factor have met the requirements: Factor loading factor (Factor loading) $1>0.908>0.5$ is suitable for multiplication analysis element. Bartlett test with Sig $=0.000<0.05$ : showing the correlation variables in the overall (Table 8). Percentage of variance (Percentage of variance) $=71,156 \%>50 \%$ : Factor analysis explains $71,156 \%$ of dependent variables (Table 9).

Table 8

KMO and Bartlett's Test

\begin{tabular}{|c|c|c|}
\hline \multicolumn{3}{|c|}{ Kaiser-Meyer-Olkin Measure of Sampling Adequacy. } \\
\hline \multirow{3}{*}{ Bartlett's Test of Sphericity } & Approx. Chi-Square & 7378.015 \\
\hline & Df & 351 \\
\hline & Sig. & .000 \\
\hline
\end{tabular}

Table 9

Total Variance Explained

\begin{tabular}{|c|c|c|c|c|c|c|c|c|c|}
\hline \multirow{2}{*}{$\begin{array}{l}\text { Compo- } \\
\text { nent }\end{array}$} & \multicolumn{3}{|c|}{ Initial Eigenvalues } & \multicolumn{3}{|c|}{ Extraction Sums of Squared Loadings } & \multicolumn{3}{|c|}{ Rotation Sums of Squared Loadings } \\
\hline & Total & $\%$ of Variance & Cumulative $\%$ & Total & $\begin{array}{c}\% \text { of Vari- } \\
\text { ance }\end{array}$ & $\begin{array}{c}\text { Cumulative } \\
\%\end{array}$ & Total & $\begin{array}{c}\% \text { of Vari- } \\
\text { ance }\end{array}$ & $\begin{array}{c}\text { Cumulative } \\
\%\end{array}$ \\
\hline 1 & 10.597 & 39.248 & 39.248 & 10.597 & 39.248 & 39.248 & 8.148 & 30.180 & 30.180 \\
\hline 2 & 4.088 & 15.142 & 54.390 & 4.088 & 15.142 & 54.390 & 4.277 & 15.843 & 46.022 \\
\hline 3 & 3.223 & 11.935 & 66.326 & 3.223 & 11.935 & 66.326 & 4.075 & 15.091 & 61.113 \\
\hline 4 & 1.304 & 4.831 & 71.156 & 1.304 & 4.831 & 71.156 & 2.712 & 10.043 & 71.156 \\
\hline 5 & .984 & 3.643 & 74.800 & & & & & & \\
\hline 6 & .918 & 3.399 & 78.199 & & & & & & \\
\hline 7 & .805 & 2.983 & 81.182 & & & & & & \\
\hline 8 & .693 & 2.568 & 83.750 & & & & & & \\
\hline 9 & .666 & 2.465 & 86.214 & & & & & & \\
\hline 10 & .506 & 1.873 & 88.087 & & & & & & \\
\hline 11 & .469 & 1.736 & 89.823 & & & & & & \\
\hline 12 & .430 & 1.592 & 91.415 & & & & & & \\
\hline 13 & .404 & 1.496 & 92.911 & & & & & & \\
\hline 14 & .377 & 1.395 & 94.306 & & & & & & \\
\hline 15 & .304 & 1.127 & 95.433 & & & & & & \\
\hline 16 & .221 & .820 & 96.253 & & & & & & \\
\hline 17 & .183 & .679 & 96.932 & & & & & & \\
\hline 18 & .169 & .626 & 97.558 & & & & & & \\
\hline 19 & .140 & .518 & 98.076 & & & & & & \\
\hline 20 & .125 & .464 & 98.540 & & & & & & \\
\hline 21 & .095 & .351 & 98.891 & & & & & & \\
\hline 22 & .068 & .251 & 99.142 & & & & & & \\
\hline 23 & .062 & .228 & 99.371 & & & & & & \\
\hline 24 & .057 & .210 & 99.580 & & & & & & \\
\hline 25 & .047 & .174 & 99.754 & & & & & & \\
\hline 26 & .035 & .131 & 99.885 & & & & & & \\
\hline 27 & .031 & .115 & 100.000 & & & & & & \\
\hline
\end{tabular}

Extraction Method: Principal Component Analysis. 
Table 10

Descriptive Statistics

\begin{tabular}{cccccc}
\hline & N & Minimum & Maximum & Mean & Std. Deviation \\
\hline PRESS.AWA & 250 & 3.00 & 5.00 & 3.9520 & .69254 \\
\hline PRESS.INFORM & 250 & 3.00 & 5.00 & 3.9880 & .71967 \\
\hline AWAR.STRA & 250 & 3.00 & 5.00 & 3.3080 & .50414 \\
\hline AWAR.CHANGE & 250 & 3.00 & 5.00 & 3.3280 & .51133 \\
\hline AWAR.BENEFI & 250 & 2.00 & 5.00 & 3.2720 & .49699 \\
\hline CHARAC.SCALE & 250 & 2.00 & 5.00 & 3.0680 & .79113 \\
CHARAC.PRODUC & 250 & 2.00 & 5.00 & 3.1200 & .78234 \\
\hline CHARAC.LOCAL & 250 & 2.00 & 5.00 & 3.1040 & .78973 \\
\hline LAW.LICENCE & 250 & 3.00 & 5.00 & 3.9560 & .69570 \\
\hline LAW.DISCLO & 250 & 3.00 & 5.00 & 3.7760 & .57893 \\
BARR.FINAN & 250 & 2.00 & 5.00 & 3.7280 & .99699 \\
\hline BARR.INFORM & 250 & 2.00 & 5.00 & 3.7160 & .74131 \\
\hline BENE.BRAN & 250 & 2.00 & 4.00 & 2.7760 & .48036 \\
\hline BENE.EFFICIEN & 250 & 3.00 & 4.00 & 3.2680 & .44381 \\
BENE.SUSTAN & 250 & 3.00 & 5.00 & 3.9240 & .63864 \\
EAAS & 250 & 3.00 & 5.00 & 4.2280 & .49090 \\
\hline Valid N (listwise) & 250 & & & & \\
\hline
\end{tabular}

Likert scale of 5 levels, the authors have a score of 3 as an intermediary, if 3-5 means the respondent agrees to the point of the given variable, otherwise if 1-3 respondents do not agree with perspective of the variable: Cognitive variable Pressure of awareness (PRESS.AWAR), Pressure on information (PRESS.INFOR), Pressure on operating license (LAW.LICENCE) with great Mean value $(>3,9)$ demonstrating these variables have a great influence on the application of environmental accounting for sustainable development. Std.Deviation column: The smaller the value, the more likely that the respondents of the views are not much different from each other. On the contrary, if the value is large, it is shown that the survey object has very different opinions for that variable. with the above data, Pressure of finance (BARR.FINAN has many views of different respondents: Std.Deviation $=0.99699)($ Table 10)

\section{Test the difference}

The authors use the Average Valuation Method to consider whether there is a difference in awareness of application environmental accounting for sustainable development among different objects? Firstly, the authors use the Independent Sample TTest Method to verify the average difference in case of qualitative variables with two values:

1) For job position (POSITION): 2 values are ADMINISTRA and ACCOUNTANT

Table 11

Group Statistics

\begin{tabular}{llcccc}
\hline & POSITION & $\mathrm{N}$ & Mean & Std. Deviation & Std. Error Mean \\
\hline \multirow{2}{*}{ EAAS } & Administra & 66 & 4.9848 & .12309 & .01515 \\
& Accountant & 184 & 3.9565 & .20449 & .01508 \\
\hline
\end{tabular}

Table 12

Independent Samples Test

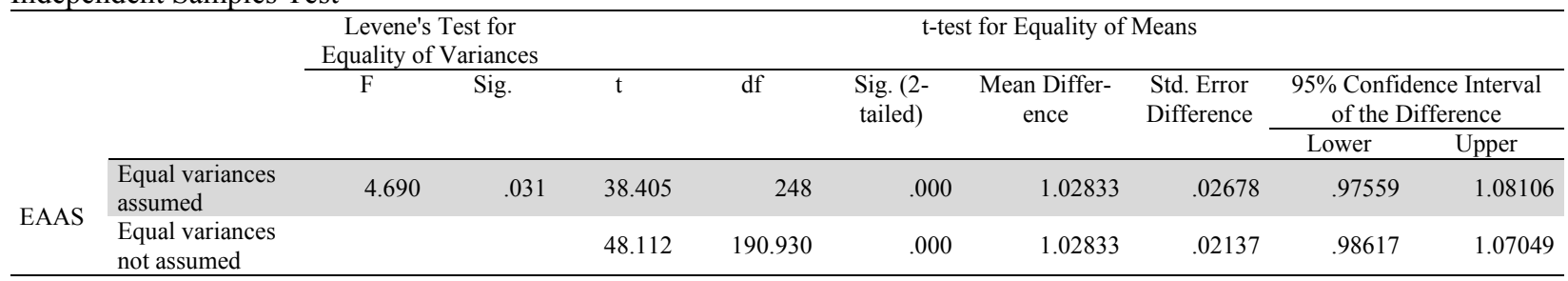

In this case: Sig Levene's Test $=0.000<0.05$ and Sig T-Test (Equal variances not assumed) $=0.000<0.05$, thus leading to conclusions: There are differences in opinion of environmental accounting application for sustainable development (EAAS) between ADMINISTRA and ACCOUNTANT (Tables 11,12) 
In this case: Sig Levene's Test $=0.000<0.05$ and Sig T-Test (Equal variances not assumed) $=0.000<0.05$, thus leading to conclusions: There are differences in opinion of EAAS between enterprises in Mining \& Processing area and enterprises in Production area.

2) For ownership (OWNER): State and Non-State and Zone export production (EPZ): EPZ and Non-EPZ, conclude: there is a difference in opinion of EAAS between state-owned and non-state owned enterprises, between businesses located in the Export production Zone (EPZ) and Non-EPZ areas. In case the control variable has 3 values, the authors use the method One - Way ANOVA and conclude: There is no difference of EAAS in enterprises with different number of employees (EMPLOYEE) and different equity (EQUITY). There are differences of enterprises in EAAS with different revenue levels.

Multivariate regression analysis

Table 13

The summary of the results

\begin{tabular}{|c|c|c|}
\hline R Square & Adjusted R Square & Std. Error of the Estimate \\
\hline .782 & .767 & .23710 \\
\hline
\end{tabular}

Adjusted R Square is used to evaluate the appropriateness of the multivariate regression model, the Adjusted R Square is 0.767 meaning $76.7 \%$ of the variation of the dependent variable EAAS is explained by independent factors (Table 13). This shows that this linear regression model is consistent with the sample data set at $76.7 \%$, i.e. the independent variables explain $76.7 \%$ of the variation of the EAAS.

Table 14

The results of ANOVA test

\begin{tabular}{|c|c|c|c|c|c|c|}
\hline Model & & Sum of & $\mathrm{df}$ & Mean Square & $\mathrm{F}$ & Sig. \\
\hline \multirow{3}{*}{1} & Regression & 46.906 & 16 & 2.932 & 52.148 & $.000^{\mathrm{b}}$ \\
\hline & Residual & 13.098 & 233 & 0.056 & & \\
\hline & Total & 60.004 & 249 & & & \\
\hline
\end{tabular}

a. Dependent Variable: EAAS

b. Predictors: (Constant), BENE.SUSTAN, BARR.FINAN, AWAR.BENEFI, LAW.DISCLO, BENE.EFFICIEN, BARR.INFORM, LAW.LICENCE, BENE.BRAN, PRESS.İNFORM, CHARAC.PRODUC, AWAR.CHANGE, AWAR.STRA, CHARAC.LOCAL, PRESS.COMMITM, CHARAC.SCALE, PRESS.AWA

The value of $\mathrm{F}=52.148$ with $\mathrm{Sig}=0.000<5 \%$ shows that the R-Square of the whole is different from 0 . That means the linear regression model is suitable for the whole (more specifically, the R squared whole will certainly be different from 0 , but not 0 then prove that independent variables affect the dependent variable) (Table 14). Thus, the hypotheses are accepted. Looking at the Beta coefficient, explains the following, for example the Beta coefficient of AWAR.BENEFI is 0.203 and it means that when the AWAR.BENEFI variable increases by 1 unit, the EAAS variable increases by 0.203 units. In addition, it can be compared to determine the influence of factors: the greater the factor B is, the more likely it is that the factor has a higher degree of influence than other factors in the research model. The impact on the application of environmental accounting for sustainable development, the administrator's awareness on costs and benefits have the most significant on EAAS (AWAR.BENEFI = 0.203), followed by Characteristics of the scale of production and business activities of enterprises $($ CHARAC.SCALE $=0.18)$ ), administrator's perception of environmental change (AWAR.CHANGE $=0.13$ ), pressure to publish sustainable environmental information and reports (LAW.DISCLO $=0.079$ ), sustainability, influences on the creation of value, risk and liability of the company (BENE.SUSTAN $=0.06)$ (Table 15)

\section{Discussion}

Companies are important contributors to economic, environmental and social well-being. The company's activities greatly affect the long-term sustainability of the economy and society. In this context, environmental accounting for sustainable development serves to collect, analyse and communicate information about corporate sustainability. It becomes the decisive factor for environmental protection and sustainable management of the company. This paper has aimed to discuss the contents, methods of measurement and approach of environmental accounting for sustainable development. The objective of the paper was to analyse the factors affecting the application of environmental accounting for sustainable development. The results have shown that, applying environmental accounting for sustainable development may depend on many different factors, in which: the most important factors were: The view of senior manager on the benefits and costs of implementing environmental accounting (AWAR.BENE), Scale of business (CHARAC.SCALE), High-level manager awareness of uncertainty, change of 
environment (AWAR .CHANGE). The results are consistent with the studies of Nnaemeka et al. (2017). From the above studies, the authors give some recommendations that could be applied in Vietnam as follows:

- Environmental accounting for sustainable development needs to implement the control to reduce energy costs and use energy most effectively. Energy audits with city budget or public-private partnerships can help with the implementation of this solution.

- In businesses, the government needs to exempt tax for income generated from efficient and energy-efficient activities.

- It is necessary to issue an account system reflecting income, expenses, assets and environmental capital sources.

Table 15

The summary of the regression estimate

\begin{tabular}{|c|c|c|c|c|c|c|c|c|}
\hline \multicolumn{2}{|c|}{ Model } & \multicolumn{2}{|c|}{ Unstandardized Coefficients } & \multirow{2}{*}{$\begin{array}{c}\begin{array}{c}\text { Standardized } \\
\text { Coefficients }\end{array} \\
\text { Beta }\end{array}$} & \multirow[t]{2}{*}{$\mathrm{T}$} & \multirow[t]{2}{*}{ Sig. } & \multicolumn{2}{|c|}{ Collinearity Statistics } \\
\hline & & $\mathrm{B}$ & Std. Error & & & & Tolerance & VIF \\
\hline \multirow{16}{*}{1} & (Constant) & 1.374 & .267 & & 5.152 & .000 & & \\
\hline & PRESS.AWA & .072 & .074 & .101 & .965 & .033 & .593 & 1.685 \\
\hline & PRESS.İNFORM & .055 & .059 & .080 & .927 & .035 & .126 & 7.946 \\
\hline & AWAR.STRA & .052 & .066 & .053 & .787 & .043 & .204 & 4.901 \\
\hline & AWAR.CHANGE & .130 & .056 & .135 & 2.303 & .022 & .271 & 3.690 \\
\hline & AWAR.BENEFI & .203 & .066 & .205 & 3.087 & .002 & .211 & 4.728 \\
\hline & CHARAC.SCALE & .180 & .062 & .290 & 2.900 & .004 & .176 & 5.681 \\
\hline & CHARAC.PRODUC & .027 & .045 & .043 & .593 & .055 & .180 & 5.546 \\
\hline & CHARAC.LOCAL & .061 & .052 & .098 & 1.187 & .023 & .136 & 7.346 \\
\hline & LAW.LICENCE & .027 & .029 & .039 & .939 & .034 & .552 & 1.813 \\
\hline & LAW.DISCLO & .079 & .031 & .093 & 2.576 & .011 & .723 & 1.383 \\
\hline & BARR.FINAN & -.049 & .019 & -.100 & -2.618 & .009 & .640 & 1.562 \\
\hline & BARR.INFORM & -.037 & .025 & -.055 & -1.452 & .014 & .642 & 1.557 \\
\hline & BENE.BRAN & .028 & .041 & .027 & .676 & .040 & .568 & 1.759 \\
\hline & BENE.EFFICIEN & .008 & .040 & .007 & .205 & .036 & .713 & 1.402 \\
\hline & BENE.SUSTAN & .060 & .032 & .078 & 1.883 & .031 & .545 & 1.833 \\
\hline
\end{tabular}

\section{Conclusion}

There is no doubt that there are many studies conducted on sustainable accounting, but the issue of environmental accounting for sustainable development has not been investigated significantly. This research has great significance because it shows the approaches, content, measurement methods of environmental accounting for sustainable development. It shows the factors that influence the application of environmental accounting for sustainable development. This study helps companies pay attention to managing costs and income related to the environment, directing businesses towards implementing the criteria of sustainable development. Since then, if well managed, enterprises will improve their competitiveness.

\section{References}

Bebbington, J., Unerman, J., \& O’DWYER, B. R. E. N. D. A. N. (2014). Introduction to sustainability accounting and accountability. In Sustainability accounting and accountability (pp. 21-32). Routledge.

Epstein, P. R., Buonocore, J. J., Eckerle, K., Hendryx, M., Stout Iii, B. M., Heinberg, R., ... \& Doshi, S. K. (2011). Full cost accounting for the life cycle of coal. Annals of the New York academy of sciences, 1219(1), 73.

Hanini, E., \& Abdullatif, M. (2013). Auditing the statement of cash flows for Jordanian public listed companies. International Journal of Business and Management, 8(4), 123.

Jeffery, S., Knechtle, B., Rüst, C. A., Knechtle, P., Rosemann, T., \& Lepers, R. (2012). European dominance in Triple Iron ultra-triathlons from 1988 to 2011. Journal of Science and Cycling, 1(1), 30.

Krausmann, F., Schandl, H., Eisenmenger, N., Giljum, S., \& Jackson, T. (2017). Material flow accounting: measuring global material use for sustainable development. Annual Review of Environment and Resources, 42, 647-675.

Ngwakwe, C. C. (2012). Rethinking the accounting stance on sustainable development. Sustainable Development, 20(1), 2841.

Nnamani, J. N., Onyekwelu, U. L., \& Ugwu, O. K. (2017). Effect of sustainability accounting and reporting on financial performance of firms in Nigeria brewery sector. European Journal of Business and Innovation Research, 5(1), 1-15.

Poveda, C. A., \& Young, R. (2015). Potential benefits of developing and implementing environmental and sustainability rating systems: Making the case for the need of diversification. International Journal of Sustainable Built Environment, 4(1), 1-11.

Raju, K. K., \& Rao, P. H. (1970). Structural Changes in Role of Accounting in Modern Business Arena for Sustainable Development. The Journal of Internet Banking and Commerce, 21(2).

Terama, E., Milligan, B., Jiménez-Aybar, R., Mace, G. M., \& Ekins, P. (2016). Accounting for the environment as an economic asset: global progress and realizing the 2030 Agenda for Sustainable Development. Sustainability science, 11(6), 945-950. 
(C) 2020 by the authors; licensee Growing Science, Canada. This is an open access article distributed under the terms and conditions of the Creative Commons Attribution (CC-BY) license (http://creativecommons.org/licenses/by/4.0/). 